DOI: 10.20472/IAC.2017.034.046

FEDERICO REGGIO

University of Verona dpt. of Legal Sciences, Italy

MARINA SARTOR HOFFER

Free University of Bozen dpt. Education, Italy

\title{
EDUCATING TO DIALOGUE: CONNECTING AN ARGUMENTATIVE APPROACH TO MEDIATION AND EDUCATIONAL TRANSACTIONAL ANALYSIS. SOME TRANSKILLS SIGNPOSTS FOR PROMOTING INCLUSIVE AND PARTICIPATIVE SOCIETIES.
}

\begin{abstract}
:
The acquisition of relational skills is one of the main goals of an educational system that aims at promoting non-violent, inclusive and participative societies. Dialogue is the key factor for such purpose, acting both as a means and as a goal that education ought to achieve.

According to this perspective, education to dialogue matches ethical-behavioural aspects (dialogue as expression of interconnectedness) and logical-argumentative competences (dialogue as instrument of communication). Such elements trace connected dimensions: (1) the ability of managing a healthy communication, which implies both correct reasoning and effective expression; (2) the ability of creating and managing a situation of communicative reciprocity, which is an instrument for preventing and transforming conflict.

The goal of this paper is to outline some conceptual and methodological signposts for the education to dialogue in light of the classical notion of 'maieutic', by drawing perspectives, concepts and methodologies from both Conflict Mediation and Educational Transactional Analysis. This transkills outline is directed to those who are professionally involved at all levels of education, with the purpose of offering a first conceptual framework for developing programmes and proposals aimed at introducing and empowering communicative attitudes and skills.
\end{abstract}

\section{Keywords:}

Mediation Methodologies; Educational Transactional Analysis Methodologies; Conflict prevention \& transformation; Education to Dialogue; Argumentation; Life Planning; Existential Positions.

JEL Classification: 129, K39, K40 


\section{Introduction and general perspective ${ }^{1}$}

The ability of managing a healthy communication, which implies both correct reasoning and effective expression, is therefore meant to match with the ability of creating and managing a situation of communicative reciprocity, which is strongly connected to the issue of preventing and transforming conflict ${ }^{2}$. Lacking or incorrect communication plays a role in the development and escalation of conflict, while, on the opposite side, the ability of managing correct interpersonal relationships through communication is a key-factor for preventing conflict and, in case of its occurrence, for preventing its escalation and promoting relational paths for transforming its destructive potential into a constructive interpersonal confrontation ${ }^{3}$.

For this reason one of the main goals of a contemporary educational system is the education to dialogue, meant both in its ethical-behavioural aspects, in which dialogue is seen and promoted as an expression of respectful and healthy interconnectedness between persons, and in its logical-argumentative character, as dialogue is an instrument of communication ${ }^{4}$. We can therefore state that dialogue even more than mere communication - is a key factor in the promotion and protection of non-violent, inclusive and participative societies.

Educators are called to teach the concept and art of dialogue and provide students with perspectives and instruments that help young generations develop a dialogical attitude, supported by those relational, communicational and argumentative competences and skills that are jointly required.

In this paper we intend to draw a few perspectives and methodologies from disciplines directly involved in a 'promoting dialogue' as a tool for preventing and solving conflict - as Conflict Mediation ${ }^{5}(\mathrm{CM})$ and Educational Transactional Analysis (ETA) ${ }^{6}$ - and outline some conceptual coordinates as signposts for an education that assumes, among its goals, the task of an education to dialogue ${ }^{7}$.

The above-mentioned connection between the behavioural and communicative components that dialogue itself embodies explains why this work has developed, since its initial conception, within a transkills framework, whose common roots can be found in the notion of maieutic to dialogue, which will be later furtherly outlined.

\footnotetext{
1 Authors: Federico Reggio and Marina Sartor Hoffer

2 See, e.g.: (Walton \& Krabbe 1995); (Stewart \& Milt 1995); (Lederach 2003); (Galtung 1996)

${ }^{3}$ See (Schirch \& Campt 2007); (Kraybill \& Wright 2006); (Lederach 2005); (Mayer 2000); (Winslade \& Monk 2001); (Cooley 1993)

${ }^{4}$ An exhaustive bibliography on such a vast and multi-dimensioned argument is out of range for this writing. We would like, nevertheless, to briefly refer to works which have played a vital role in the definition of the conceptual basis of this presentation. On the connection between the logical, argumentative and ethical aspects of the notion of dialogue see, e.g.: (Habermas 1986); (Habermas 2007); (Cavalla 1990); (Cavalla 2017); Wouther Slob, Dialogical Rhetoric. An Essay on Truth and Normativity After Postmodernism. (Dordrecht-Utrecht: Springer, 2002).; (Vendemiati 2007); (Calogero 1977); (Buber 1947) - (Berne 1972), (Barrow, Newton 2016); (Harris 2000) (Schulz von Thun 1981); (Bobbio 2012); (Romanini 2008); (Bruzzone 2007); (Temple 2007)

${ }^{5}$ Conflict Mediation will be abbreviate with "CM"

${ }^{6}$ Educational Transactional Analysis will be abbreviate with "ETA"

${ }^{7}$ On an approach to mediation strongly connected with the notion of dialogue in its argumentative character, see: (Cooley 1994); (Kraybill et al. 2000); (Greco Morasso 2011); (Reggio 2017) On Eric Berne's TA, see, for a complete bibliography, www.ericberne.com/eric_berne_bibliography; see, as particularly meaningful examples:
} 


\section{Conflict, dialogue and mediation ${ }^{8}$.}

Dialogue is challenged by the occurrence of conflict. Conflict challenges relationships: it occurs within relationships and impacts on them.

In facing such phenomenon, legal systems include a variety of instruments designed to offer processes through which parties are called to confront themselves in order to habilitate a legal decision. The legal process - in the form of a fair trial - requires an adversarial debate, with a highly legal-technical feature, whose outcome results in a decision given from a third subject, and therefore operates within a win/lose, adjudicative logic. Dialogue takes place in a highly formalized way, in which dialectics, on one hand, and legal warranties on the other, provide a rigid frame: here, the direct participation and role of the parties involved in the conflict is not central. While the legal trial cannot be fully replaced by other tools, the contemporary debate - most explicitly the one on Alternative Dispute Resolutions - has revealed a widespread discomfort towards the traditional approach to interpersonal conflict that legal systems tend to offer ${ }^{9}$. On a parallel side, such growing awareness has also witnessed an increased proposal of legal tools and methodologies meant to offer more participative and person-centred approaches to conflict resolution.

Within such a flow, Conflict Mediation, in particular, offers an alternative to the trial, designed in a way that parties are directly involved to actively participate in a dialogue and to negotiate, with the help of a mediator, a decision that results suitable to their interests and needs. Mediation, therefore, aims at an autonomous, voluntary cooperation directed to researching a sustainable agreement between the parties themselves, whose consensus is a key-factor in the whole process: it is required for the confrontation to begin and develop, and it is necessary in order to achieve an agreement, within a non-adjudicative but rather cooperative logic, and with the ideal goal of outlining a win/win solution ${ }^{10}$.

Although consensus and negotiation are important factors, different approaches to mediation tend to put the accent on different key-ingredients, varying from the role of emotions to the role of empowerment and recognition, to the importance of the narratives that parties construct and de-construct with the help of a mediator. Despite the above-mentioned differences, a common factor that all these approaches do not deny is the fact that mediation requires a communicative situation between the parties and among all participants, including the mediator and, eventually, the lawyers: it occurs through a dialogue, enabled by the personal participation of the parties, and by some ground rules of interaction that are necessary to help such confrontation develop in a respectful, constructive and reasonable way ${ }^{11}$.

\footnotetext{
${ }^{8}$ Author: Federico Reggio.

${ }^{9}$ It is not possible to fully acknowledge such a wide debate. Some of its most remarkable examles, nevertheless can be found in: (with specific reference to criminal justice) (Christie 1977); (Hagel \& Barnett 1977); (Zehr 1990); (Wright 1991); (Cornwell et al. 2013) With reference to civil justice: (Abel 1982); (Auerbach 1983); (Sander 1979); (Association 2006); (Smith 1996)

10 See: (Reggio 2017)

11 See: (Maiese 2004)
} 
Some scholars have, therefore, put a strong accent on the fact that at the core of mediation there is a notion (and a practice) of reasoned dialogue, that is better understood if read through the categories of argumentation ${ }^{12}$. According to this approach, mediation is not only based on a simple, spontaneous 'communication': it requires, instead, the attempt of matching emotions, behaviours and reasons in light of a rationally controlled exercise of argumentation.

Drawing from John William Cooley's proposal, communication in mediation is some sort of meeting place, where pathos (emotions) and ethos (behaviour) are connected and shaped into rationally-understandable and communicative forms by logos (reason) ${ }^{13}$. Such synthesis enables a true (and reasonable) dialogue, and not a mere exchange of opinions, as a sound consensus emerges when parties succeed in rationally supporting and testing the sustainability of their assertions through argumentations ${ }^{14}$. This way, consensus is not a mere meeting of wills, but rather an encounter of reasons and the outcome of a search for common grounds and outputs. The American author re-read the classical notion of rhetoric, mainly by rediscovering the heritage of Plato and Aristotle, and suggested that the mediator can be better understood in light of the Socratic notion of 'maieutic': the mediator itself is seen as a 'maia', a nurse who helps dialogue be born and developed correctly. According to such perspective, mediation is not shrunk within the idea of a facilitated negotiation, but is rather constructed around a dialogue that requires an attitude and a practice of active listening, a respectful explanation of each other's viewpoints on the problem, as well as an exploration of differences and commonalities in order to commonly search for the possibility of an agreed-upon solution, taylor-made around the specificities that the case has revealed during - and through - the dialogical confrontation of the parties.

In a sense, mediation can be a practiced process meant to "educate" conflicting parties to face the challenge of a dialogue based on mutual respect and recognition, and animated by an openness to expressing reasons, emotions, needs and viewpoints, and listen to those of other people with whom there's an ongoing conflict of some sort.

Developing capabilities and skills that enable to recur to dialogue rather than to expressions of force and self-affirmation turns to be a key objective for any society that intends to foster inclusive and non-violent relationships, and to avoid the destructive potentials of conflict, either by preventing its rooting or by transforming its momentum into a positive shift towards a constructive change.

This is why the possibility of offering to students - at different stages of their educational path - at least an embryonic introduction into some of the notions and abilities that embody the correct training of a mediator could actually be seen also as a key educational goal in our contemporary societies, in which young generations are

\footnotetext{
12 See: (Cooley 2006); (Greco Morasso 2012); (Reggio 2017).

13 See: (Cooley 1993); (Cooley 1994).

${ }^{14}$ On reasonableness in mediation see: (Greco Morasso 2011)
} 
constantly challenged by the difficulty of developing correct social and relational skills, meant to prevent the eventuality of violence and prevarication at different levels.

If we agree on this perspective, then also educators should be provided with perspectives, notions, methodologies and skills that allow them to perform their role of educators to dialogue.

\section{Conflict, Dialogue and Educational Transactional Analysis ${ }^{15}$.}

Mainly well-known for its use in psychotherapy and counselling, Eric Berne's Transactional Analysis (TA) offers a wider range of perspectives and methodologies, whose utility has been extended to other fields. For instance, thanks to the proposals of practitioners such as Giles Barrow and Trudy Newton ${ }^{16}$ and Susannah Temple ${ }^{17}$, TA has been developed, in recent decades, also an educational thread. On a parallel stream, TA has witnessed developments related to the field of conflict prevention and management, including, for example, situations of impasse or conflict in the workplace. Such flexibility depends on the fact that TA matches a rather simple and adaptable structure, supported by a theoretical background that allows practices to be grounded on a general philosophy.

Maria Teresa Romanini ${ }^{18}$ poignantly defined TA as a philosophy originating from Personalism and at the same time as a Personality Theory. Designed by Eric Berne $(1910-1970)^{19}$, TA considers the person as inseparable from his network of relationships, and aims to analyze human behavior in its aspect of communication. The milestone of his perspective is that behaviors and decisions are not deterministic but can rather be changed.

At the core of Eric Berne's proposal we can find the Structural Diagram ${ }^{20}$. Through the image of three overlapping circles called Ego-States, Berne mapped the three instances of the personality (Adult, Parent, Child-Ego State) that activate in each Transaction (smallest unit of relationship between persons, which translates into repetitive and easily recognizable behaviors). The Ego-States represent, respectively: the elaboration of the facts that the person directly experiences $(A)$; the behaviors and thoughts copied by the parents $(\mathrm{P})$, and the feelings experienced during childhood and relived in the present $(\mathrm{C})$. The optimal transaction in a communication between two persons is between each other's A-Ego State; in the alternative, however, it is desirable between parallel instances. If the transaction is crossed (between different instances) the communication stops, giving rise to misunderstandings and quarrels. The Adult Ego-state, called "Integrated Adult", listens and verifies the data coming

\footnotetext{
${ }^{15}$ Author: Marina Sartor Hoffer.

${ }^{16}$ Giles Barrow and Trudi Newton, 2016

17 Temple S., 1998b,

18 Romanini, 1999, Costruirsi Persona, Various articles in which the Author considers TA as a Philosophy of Personalism

${ }^{19}$ For the complete bibliography of Eric Berne, see: (2013) www.ericberne.com

${ }^{20}$ see, between many others,:Steward, I. \& Joines V., (2000)
} 
from the other Ego-States and examines whether the information is consistent with reality, and then it decides the consequent behavior.

If a subject reaches the awareness of its own transactions and those of the people with whom it communicates, it recognizes the dynamics of a possible discomfort and can freely decide to disable transactions that give rise to unproductive behavior. In Educational Transactional Analysis, the purpose of an educator is not to diagnose or treat diseases related to "contaminations" of the Ego-States, but in promoting awareness through the activation of the "Integrated Adult", which is the instance of the personality that knows how to act effectively on the present integrating both the teachings of the Parent and the needs of the Child Ego-States.

Eric Berne realized that each person carries out a plan of life decisional Life-Plan, which he defined as a Script. "Life script is an unconscious life-plan, made in childhood, reinforced by parents, justified by subsequent events, and culminating in a chosen alternative"21. The origin of it is placed in a survival strategy. At the basis of the Script (whose analysis and therapy does not concern the educational environment) are the Existential Positions, called Ok-Corral: they are basic ideas about themselves and others, useful to motivate choices and behaviors that are based on essential and obvious values and can easily be gained to our awareness ${ }^{22}$. The existential positions are four, and describe how a person sees himself and the others. (The + and-signs indicate a positive or negative assertion related to the existential position):

- Optimal status $=$ I am OK; You are OK: ++ (healthy existential position, which induces assertive behavior)

- Aggressive state = I am OK; You're not OK: +-(rabid behavior, frustration, sense of superiority)

- Inadequacy status = I am not OK; You are OK:-+ (passive behavior, serval; depression)

- Status of nihilism = I am not OK; You are not OK:--(destructive behavior, hopeless, sense of impotence)

Even the Strokes (acknowledgments), identified by Berne as the basic needs of the person, are grounded on our existential position, and that is why it is important for each person to be aware of her own level of OK-ness. Berne coined the term "stroke" to describe our "Hunger for Recognition"; the term is also translated with "caresses", and indicates an interrelational message that, if it has a response, triggers a transaction. A negative, positive or conditioned stroke makes an acknowledgment of the person of the other: or confirms its state of underestimation, or recognizes it for what it is (making possible unconditional acceptance and activating in this way parallel transactions), or expresses a conditional acceptance, in which the person does not apply for what it is, but for what it does.

\footnotetext{
${ }^{21}$ E. Berne,1972, page.446

22 See: Thomas, A. Harris, (2000)
} 
The possibility of offering to students and to their teachers - at different stages of their educational path - at least a first introduction into some of the above mentioned notions and tools could play a vital role in understanding the underlying relational dynamics, with a subsequent positive rebound in enhancing their communicational skills.

\section{CM and ETA: outlining common grounds and purposes ${ }^{23}$.}

This first brief outline allows us to argue that CM and TA can be connected and worthy combined, as they share both some conceptual premises and goals.

As for the sheer premises, some of the most remarkable are: (1) people and relationships are central; (2) behavioral problems - including those related to interpersonal conflict - are analyzed and dealt with through communicational interactions between the stakeholders; (3) in facing conflict and the issue of its solution, the direct and personal contribution of the people involved are a key factor; (4) the solution to a conflict is not seen as an application of pre-determined rules, but rather as a personalized, context-sensitive outcome; (5) conflict is managed through processes oriented to transformative outcomes, meant to enable a constructive change on how conflict, its solution, and the relationships involved, are viewed and experienced.

Points 3,4 and 5 outline also goals that both CM and ETA seek to pursue, and this helps tracing a further commonality, as one of the highlights of both these approaches is their characteristic of (6) being future-oriented: mediation, on one hand, differs from the legal process since it is not meant to offer adjudicative solutions that "close the case" in a Win/Lose way but rather aims at Win/Win, consensus-based solutions; ETA, on the other hand, differs from classical psychotherapeutic approaches since it does not deal with detecting the causes of a certain behavior, but rather offers techniques for addressing it with consciousness and in a way that is transformative as it likely happens also when mediation fully succeeds.

The aspect of ETA that mostly matches with the aims of this presentation consists in its usefulness in the analysis of communicative interactions (transactions) as well as in its potential in promoting positive changes within their participants. This is, nevertheless, another commonality with $\mathrm{CM}$, mostly when it is considered through the lens of an argumentative approach, that emphasizes the communicative interaction as a core element of conflict resolution.

${ }^{23}$ Authors: Federico Reggio and Marina Sartor Hoffer. 


\section{Strategies and methodologies in the educational field: developing perspectives and skills for a correct interpersonal interaction ${ }^{24}$.}

The knowledge and management of the Structural Model and the Functional one can be the key to solving thorny situations and improving communication ${ }^{25}$. With a brief training, the use of this model is easy and smooth ${ }^{26}$. Often the problems, if faced in a parallel transaction from A to A - Ego-state, they find solution: the awareness of dysfunctional models emerged from our experience of life and that gives rise to crosstransactions, can lead us to decide to change strategy and build a new personal and relational story.

A further strategy by mean of which ETA promotes constructive existential positions consists in the Permissions ${ }^{27}$. With them, the educator plays a very important role in promoting an education to dialogue. If we have had Restrictive Injunctions (our parents and educators have addressed negative and devaluing messages from their existential positions), the educator can depotentiate them with an antidote: "Permissions" instead of "Bans". A person may have been "forbidden" to exist, to be himself, to have satisfaction from a well-done job, to have good social relations, and so on. "Bans" can be of any kind, here we have appointed only a few. Often a permission granted by an educator - when it is sincere and accompanied by the right tone of voice and the right posture - changes the life of a pupil, or benefits the relations between colleagues. The granting of "permits" can also be learned by an educator through a brief training, as well as all the techniques made available by ETA.

These brief examples taken from the methodology of ETA show how a trained educator can positively interact with students, thereby promoting their own acquisition of healthy and conscious communicative habits. The core-issue deals with understanding communicative dynamics and operating within them in a way that promotes personal autonomy, responsibility and that habilitates the ability of personally solving a specific, contextual problem.

\section{Some methodologies for a maieutic of dialogue: from mediation to good communication 28}

A well-trained mediator is expected to help creating an environment of reciprocal listening and respectful interaction in which conflicting parties are invited to share viewpoints, experiences, ideas, emotions, and to jointly engage in a confrontation that aims at stretching the issue at stake with the purpose of searching for a common

\footnotetext{
24 Author: Marina Sartor Hoffer.

${ }^{25}$ see Paolo Torresan, (2015)Academia

${ }^{26}$ Mara Gerich, Simone Bruder, Silke Hertel, Monika Trittel, and Bernhard Schmitz, (2015)

27 Padeborn (1999)

${ }^{28}$ Author: Federico Reggio
} 
solution ${ }^{29}$. His communicative moves - and the style through which they are delivered - are vital in providing a "first impulse" and an example of how a correct dialogical attitude can be embodied ${ }^{30}$. One first, key element for this, is his ability of offering an active listening, in which careful listening, note-taking and paraphrasing - as well a trained art of asking questions - are directed to help the mediator and the parties to: (1) access the problem, (2) understand its different components and their character, (3) work on shaping a common language and, possibly, at least a (4) basic common understanding (which does not mean, of course, neither having common feelings and opinions, nor necessarily reaching an agreement) ${ }^{31}$.

In training such capabilities and skills, a mediator is called to understand how each conflict is a multi-layered structure, made by a variety of "ingredients" that differ from person to person, and from conflict to conflict ${ }^{32}$. This implies, for instance, learning: (1) to understand and detect the difference between a formalized position and its underlying interests and needs ${ }^{33}$; (2) to recognize and name feelings and emotions ${ }^{34}$; (3) to deal with the structural vagueness of language and to help creating common meanings and narratives ${ }^{35}$; (4) to recognize and help parties understand the difference between different types of "opposition" (not all opposed theses are incompatible) and to focus on both differences and commonalities ${ }^{36}$.

The training of a mediator seeks to help develop a multi-faceted sensitivity to the three elements that - according to our perspective - concur to shape relationships, and which are also vital in dealing with conflict: the logos (the rational side), the ethos (the behavioral side) the pathos (the emotional side) ${ }^{37}$. It also helps avoiding predetermined schemes and narratives of meaning, and to develop an open-mindedness and a curiosity (that, to quote John Paul Lederach, is para-doxal, to say that it is open to move beyond appearance, sheer opinions and commonplaces) ${ }^{38}$. This does not turn the mediator into a psychologist, as his role - despite different nuances according to the different "schools" of mediation - remains mostly facilitative, and limited to an external point of view on the conflict and the issue of its solution ${ }^{39}$. The outcome that a mediation process seeks to achieve is an informed and sound agreement, sustained

\footnotetext{
29 See, for a first overview: (Moore 1996); (Morineau 1998); (Cooley 2006). The elements of empowerment and recognition are key-factors of a mediation process according to a transformative approach. See, on this point: (Bush \& Folger 1994).

30 See (Mckinney et al. 1992)

31 (Irvine \& Farrington s.d.); (Stewart \& Milt 1995); (Jacobs \& Aakhus 2002). On the vital role of asking questions see: (Reggio 2017); (Hochmann 2006).

32 I draw this notion from: (Lederach 2003).

33 This is a central methodological point. See, for a first overview: (Fisher et al. 1991).

34 (Irvine \& Farrington s.d.).

35 See: (Cooley 1994); (Greco Morasso 2012); (Reggio 2016). On a narrative approach to mediation, see, for instance: (Winslade \& Monk 2001).

${ }^{36}$ See, on this point, my own model of argumentative conflict analysis: (Reggio 2017, chapter IV)

37 I take these suggestions from (Cooley 1993).

38 See, on paradoxal curiosity as one of the qualities that a peacebuilder should develop: (Lederach 2005).

39 See: (Stulberg 1997); (Poirer-Elliot 1998).
} 
by the consensus of the stakeholders, and shaped around their interest, needs, and the solutions that they eventually came up with ${ }^{40}$.

It is not infrequent that, as a mediation proceeds, its objects varies, as the way the issue is perceived and dealt with evolves according to the understanding of the parties and to how the mediator helps them develop strategies for effectively solving the problem: it occurs, therefore, that the overall understanding and qualification of the object changes, and so it does the perspective of the parties. This requires, from the mediator, the ability of promoting a reframing, thanks to which the conflict remains in all its richness and complexity but is envisioned in a different, often more constructive and future-oriented way ${ }^{41}$.

Argumentation offers both a common ground and a necessary toolkit for a mediator, as the above-mentioned methodologies require communicative capabilities that synthesize both logical skills (which also help maintaining impartiality), empathy and sensitivity, and the ability of working with language and narratives. This is vital at all stages of a mediation process, from its beginning to its conclusion, in which the ability of fostering common and sound agreements results a key-factor for the success of the process. In his maieutic role, then, the mediator is also a rhetor, and a good rhetor, according to a classical approach, is not focused on pursuing persuasion as a psychological fact, but rather as a result of a (mostly rational) process that is meant to check also the soundness and sustainability of a consensus ${ }^{42}$. This is vital in $\mathrm{CM}$, as its outcome, for being truly constructive and capable of promoting durable effects, cannot be ephemeral but ought to undergo a verification of its soundness and sustainability.

The elements that concur to shaping a good mediator are the result of soft and hard skills, of a theoretical and practical training, and they consolidate through experience ${ }^{43}$. Nevertheless, some of the elements that belong to the methodology of mediation are quite useful in educating each person to facing dialogue correctly, and to deal with conflict in a non-destructive way: therefore, in the path of education, some of these "ingredients" could result quite useful in shaping participative citizens, provided with ground-notions and skills on how to deal with communication as a means for preventing and constructively solving conflict.

A program of education to dialogue through mediation could include a basic introduction to the above-mentioned methodologies (e.g. active listening; understanding and analyzing conflict; techniques of dialogue facilitation), with argumentation as a fil-rouge. In a training program for schools, some basic-notions of mediation methodologies could be easily matched with other existing educational

\footnotetext{
${ }^{40} \mathrm{I}$ argued that in reaching and writing their agreement, parties and the mediator concur to formulating "the rules of the case", or, "the norm of the case", acting as self-legislators. See: (Reggio 2012).

${ }^{41}$ See: (Kinsey et al. 1993).

42 See, on mediation: (Cooley 1993); (Greco Morasso 2011). See, more generally, on such an approach to argumentation: (Cavalla 2004).

${ }^{43}$ See: (Kraybill 1988).
} 
projects focused on communicational skills, such as those, for instance, that are directed to introduce students into public speaking or public debate.

\section{Contracting for changing. Agreement on dialogue as a first common ground for dealing with conflict in a non-violent way ${ }^{44}$.}

If dialogue is seen both as a means and as a goal of a non-violent approach to preventing and solving conflicts, parties must agree, at some level, that they intend to interact in a way that does not prevent correct communicative interactions, in some cases, with the help of a facilitator. This means that, first of all parties should develop some basic common notions and basic common rules and accept to respect them, in order to reciprocally grant that they intend to solve their issue through dialogue.

This happens in mediation, for instance, when the mediator explains the notion and the goals of the process and its ground rules, and seeks to verify the understanding and the agreement of the parties on them.

On a parallel side, one of the most famous methodologies derived from Berne's doctrine is the "Contractual Approach". (TA is, by definition, already characterized by the contractual approach, being a "psychological and social theory characterized by a bilateral contract of growth and Change") 45 .

The "Contract" (understood as "an explicit bilateral commitment to a well-defined course of action" (Berne, 1967) is the main instrument that TA offers in order to promote change, and it is a strategy that can be adopted in education as well ${ }^{46}$. Berne, which had been formed as psychoanalyst, soon understood that the change should not be linked to a psychiatric diagnosis, as to a matching contract that aims to support the resources of a person left inactive. This promotes self-confidence, while in psychoanalysis is promoted the trust in the therapist. The Transaction is the center of Berne's perspective, and not the person of the psychotherapist. Self-awareness comes from the analysis of the Ego-states, and the "contractors" are only supposed to promote it. It is a precise commitment of the person towards the realization of its objectives and, at the same time, it borders the boundaries within which the "contractors" relate. It also prevents drop-outs, by helping a correct timing of objectives.

Contracts defined as "Social control-contracts" or "II level-contracts" are very remarkable in the field of education. Their objective is a behavioral change and its maintenance over time. They deal with a temporary imbalance and aim to solve the problem by energizing the Adult Ego-State. A contract can be activated between a teacher and a class; between the teacher and a pupil (and not only for the "resolving" purposes of some problems, but also for "evolutionary" purposes, where it is possible

\footnotetext{
${ }^{44}$ Authors: Federico Reggio and Marina Sartor Hoffer.

${ }^{45}$ Mastromarino, Scoliere, (1999)

46 Loomis M. (1990)
} 
to enhance situations not necessarily problematic); between the teacher and the pupil's family; among the three subjects.

The teacher plays the role of what we call "Developmental Counselor", which means being promoter of the development of good relational skills, believing that this constitutes pre-requisite for any learning. The teacher is placed in the contract as "Mediator of existential competences": he actively listens to the subjects involved, allowing him to focus on the needs. This facilitates the identification of strategies to achieve the goals, (which must be identified by the person involved, not by the educator, in order to promote the autonomy of the Adult Ego-State); it also guarantees the progress of the process through the periodic verification of the established objectives.

The educator, through the structural and functional mapping of the parent/child relationship, may, among the possible contracts, promote a reflection on the parental function C-P and N-P, to check which of the two instances tends to prevail. There is evidence that even by illustrating the Functional Diagram that emerges from this reflection, the analysis can be placed autonomously by the parents, who can easily recognize themselves in one description or another and decide for a change.

As far as Active Listening is concerned, there are many models ${ }^{47}$ in the practice of TA and counselling ${ }^{48}$, often taken from methods related to other theories. Along with the well-known method developed by Carl Rogers ${ }^{49}$, the model of Schulz von Thun ${ }^{50}$ represents valid proposals for teachers at present times.

However, in the ETA's perspective all the listening strategies require the premise of clarifying the existential positions of the subjects in play. No active listening, no contract may be placed if a priori the contractor who places himself as "facilitator", or "mediator" of the change (we prefer to define it "developmental counselor") does not have a healthy and effective existential position. In case one tried to simulate an existential position that does not match with his own actual situation, the body and the voice would betray this attempt, by revealing the real existential position. A very famous study by Mehrabian \& Ferris ${ }^{51}$ has later proven the intuition of Berne about the language of the body, as only $7 \%$ of the content of the communication is verbal (verbal), while the facial expression (visual) is responsible for $55 \%$ and the way words are expressed (vocal) (intonation, accents, etc.) reflects the $38 \%$.

Berne had made this intuition already in the article, published 1953 in The Psychiatric Quarterly52, entitled "The Nature of the communication", and had pointed out that if the

\footnotetext{
47 see Weber W., (2005)

48 G. Aich; M. Behr, (2015)

49 Rogers, Carl, (1951)

50 Schulz von Thun, (1981)

${ }^{51}$ Mehrabian, A., \& Ferris, S. R. (1967)

52 E. Berne, (1953)
} 
report is betrayed by the non-verbal, it gives rise to an inconsistency. The Developmental Counsellor must pay attention to how words are spoken, to their tone and volume, and to the language of the face and body that accompanies them. Also clarifying, paraphrasing, summarizing reflecting are further dialogue techniques that promote relationship with each other and create empathy. With them the actor can prove to have listened and understood and the interlocutor feels induced to continue the communication.

The latter examples show how some communicative methodologies that ETA suggests are common to also $\mathrm{CM}$ approaches, thereby confirming the sheer usefulness of those approaches in promoting correct relational and communicative interactions, as the purpose of this paper seeks to underline.

In this paragraph we have also highlighted the role that "contract" and "permissions" could play for the above-mentioned purposes, as well as the analysis of the structural and functional diagram, which leads to the focus on transactions, offering a formidable model for analysis and self-analysis of communication.

As a final remark, without a previous control through the formula of the OK-ness as a necessary practical premise, these strategies could take place correctly: on the contrary, the attempt to use of ETA methodologies to solve concrete problems would be doomed to failure.

\section{Conclusion: dia-logos. Connecting differences and commonalities within relationships.}

In moving towards the conclusions of this writing, we can ask ourselves why we connected the issue of a healthy and correct communicative relationship among people with the purpose of preventing and transforming conflict, and also why we considered such goals central in the field of education.

Conflict happens. It is unavoidable. What we can choose is how to deal with it: whether we want to let it express its destructive potential, or to try to turn it into a challenge for human diversity and human commonality, and, therefore, as a chance for positive change ${ }^{53}$. Conflict challenges diversity, as it often stems from different understandings, views, interest, needs, goals and values: but it also challenges commonality, as being involved in a conflict is a common problem, and engaging into the process of seeking a solution is a common challenge and requires a common commitment and a common communicative ground. This challenge is complex and requires a process of gradual connections that is better understood and achieved through the intersection of different disciplines and approaches: this explains why the signposts that this paper has outlined stem from a transkills approach, thanks to which

\footnotetext{
53 This is a core-concept of a transformative approach to conflict. See, for an overview: (Lederach 2003); (Lederach 2005).
} 
the disciplines involved needed to narrow and fine-tune their object in search for a common ground.

At the beginning of this writing we suggested that dialogue is a core-concept, by qualifying it as the alternative to violence and prevarication, acting both as a value to preserve (so, a goal), and as a means for enabling a non-violent process. A brief reminder of the origin of this word could be useful, in conclusion of this overview: the greek work "dialogos" is the combination of dia (expressing interconnectedness, but also distinction and difference) and logos (reason, a reason that acts as connection, as well as a discourse - another meaning of logos - is a meaningful connection of elements) ${ }^{54}$. Dialogos requires that we recognize relational textures in their richness and complexity and face the challenge of dealing with them as actors that are part of such a web of interconnections, and which are therefore called, at every stage and moment of our experience, to dialogically interact with other beings.

As we underlined, both $\mathrm{CM}$ and ETA consider dialogue at the center of methodologies, and as they both tend to put persons and interpersonal relationships at the center of their attention within the framework of communication This is the reason why, in a world that is daily dealing with the challenge of complexity - and with its potential in generating conflict - educating to dialogue is a realistic and adequate goal that each educational system is invited to urgently pursue. If this paper has helped showing that CM and ETA could positively concur to this, by offering perspectives, methodologies and tools that enrich educators and all the people who are involved in the educational path, then the goal of this writing has been achieved.

\section{References:}

(Marina Sartor Hoffer)

ADAMS G. (1991) Transactional analysis in education. Hong Kong

AICH G.; BEHR M., (2015), Gesprächführung mit Eltern, Weinheim und Basel

BARROW G. NEWTON T., (2016) Educational TA, an International Guide to Theory and Practice, London and New York

BERNE E., (1972) What do you say after you say hello?, New York

BERNE, E. (1953) Concerning the nature of communication, The Psychiatric Quarterly January 1953, Volume 27, Issue 1-4, pp 185-198

BERNE, E. (1964) Games people play: the psychology of human relationship, New York

BOBBIO A. (2012) (a cura di) Pedagogia del dialogo e relazione di aiuto. Teoria, azioni, esperienze. Armando Ed., Roma

${ }^{54}$ See, on this point: (Cavalla 2017); (Reggio 2017). 
BRUZZONE D., (2007) Carl Rogers, la relazione efficace nella psicoterapia e nel lavoro educativo, Carocci, Roma

CLARKE J. I. (1998)The synergistic use of five transactional analysis concepts by educators. Transactional Analysis Journal, 26, 214-219, 1996 Education,

GIBBONS, M., LIMOGES C.,NOWOTNY, H., SCHARZMANN, S., SCOTT, P., \& TROW, M., (1994). The new production of knowledge: The dynamic of science and research in contemporary societies. London, Sage

HARRIS A. THOMAS, (2000) lo sono OK, tu sei OK, Milano, Biblioteca Universale Rizzoli, (1976)

LOOMIS M. (1990) Contracting for change. Transactional Analysis Journal, vol XII, n. 1,1982 ; trad.it a cura di M.Magnino "I contratti di cambiamento" in "Neopsiche" anno 8, n¹4, dicembre 1990, pages $21-26$

MARA GERICH, SIMONE BRUDER, SILKE HERTEL, MONIKA TRITTEL, AND BERNHARD SCHMITZ, (2015) What Skills and Abilities Are Essential for Counseling on Learning Difficulties and Learning Strategies? Modeling Teachers' Counseling Competence in Parent-Teacher Talks Measured by Means of a Scenario Test, Zeitschrift für Entwicklungspsychologie und Pädagogische Psychologie, 47 (2), 62 - 71_Hogrefe Verlag, Goöttingen

MASTROMARINO R., SCOLIERE M., (1999) Introduzione all'analisi Transazionale. Il modello 101, IFREP Roma

MASTROMARINO R., Teoria e tecnica di ridecisione. Sequenze operative. Analisi Transazionale, la terapia della ridecisione, Psicologia e salute, 15

MEHRABIAN, A., \& FERRIS, S. R. (1967). Inference of attitudes from nonverbal communication in two channels. Journal of Consulting Psychology, 31(3), 248-252.

NICOLE, P., (2002) Les différents contrats', in Nicole Pierre's book Pratique de l'Analyse Transactionelle dans la Classe, published by ESF éditeur, pages 60-9, with additional material from pages 70-6.)

PADERBORN, ed., (1999) Erlaubnis zum Wachsen. Beitraege aus der Arbeit mit Transaktionsanalyse in Paedagogik und Erwachsenenbildung [Permission to grow: Articles about working with TA in education for kids and adults], Paderborn: Junfermann Verlag.

ROGERS, C., (1951) Client-Centered Therapy: Its Current Practice, Implications and Theory. London: Constable

ROMANINI, M.T. (2008) Costruirsi Persona, 2 voll., Milano, Ed. La Vita Felice

ROSSI CASSOTTANA O., (2010) Alla ricerca di una rinnovata dimensione progettuale della personalità tra percorsi scolastici ed esistenziali, Armando, Roma

SCHULZ VON THUN, (1981) Miteinander reden 1. Störungen und Klärungen. Allgemeine Psychologie der Kommunikation, Reinbeck bei Hamburg

STEWARD, I. \& JOINES V., (2000) Die Transaktionsanalyse. Freiburg Herder, 
TEMPLE S., (1998b), Teaching with TA, in in T. Laes, MK. Lerkkanen \& E. Varis (Eds), Educational TA for teachers, (Jyväskylä Studies in Education, Psychology and Social Research Rep. No 142

TEMPLE, S. (2007). Das Functional-Fluency-Modell in der Pädagogik. Zeitschrift für Transaktionsanalyse 1, 76-88.

TORRESAN, P., (2015) Transactional Analysis's motivational model as a frame of the observation and evaluation of the educational and training paths, Santa Monica college, CA, in Academia

WEBER W., (2005) Wege zum helfenden Gespräch. Gesprächspsychotherapie in der Praxis, (13. Aufl.). München: Reinhardt

(Federico Reggio)

ABEL, R., (1982). The Politics of Informal Justice, New York: Academic Press.

AMERICAN ARBITRATION ASSOCIATION, (2006). ADR and the Law, New York: Jp Juris.

AUERBACH, J.S., (1983). Justice Without Law?: Non-Legal Dispute Settlement in American History, New York: Oxford University Press.

BUBER, M., (1947). Dialogishes Leben, Zurich: Gregor Müller.

BUSH, R.B. \& FOLGER, J., (1994). The promise of Mediation: Responding to Conflict through Empowerment and Recognition, San Francisco: Jossey Bass.

CALOGERO, G., (1977). Filosofia del Dialogo, Milano: Edizioni Comunità.

CAVALLA, F., (2004). Dalla «retorica della persuasione» alla «retorica degli argomenti». Per una fondazione logica rigorosa della topica giudiziale. In La retorica fra scienza e professione legale. Milano: Giuffrè, pagg. 25-82.

CAVALLA, F., (2017). L'origine e il diritto, Milano: FrancoAngeli.

CAVAlLA, F., (1990). Sul fondamento delle norme etiche. In E. Berti, a c. di Problemi di etica: fondazione norme orientamenti. Padova: Gregoriana libreria editrice, pagg. 141-202.

CHRISTIE, N., (1977). Conflicts as Property. British Journal of Criminology, 17, pagg.1-8.

COOLEY, J.W., (1993). Classical Approach to Mediation - Part I: Classical Rhetoric and the Art of the Persuasion in Mediation. University of Dayton Law Review, 19:1, pagg.83-131.

COOLEY, J.W., (1994). Classical Approach to Mediation - Part II: The Socratic Method and Conflict Reframing in Mediation. University of Dayton Law Review, 19:2, pagg.589-632.

COOLEY, J.W., 2006. The Mediator's Handbook. Advanced Practice Guide for Civil Litigation, Boulder (CO): National Institute for Trial Advocacy Press.

CORNWELL, D., BLAD, J. \& WRIGHT, M., 2013. Civilising Criminal Justice. A Restorative Agenda for Penal Reform, Hook-Hampshire: Waterside Press.

FISHER, R., URY, W. \& PATTON, B., (1991). Getting to Yes: negotiating Agreement Without Giving In, New York: Penguin Books. 
GAltung, J., (1996). Peace by Peaceful Means. Peace and Conflict. Development and Civilization, SAGE Publications.

GRECO MORASSO, S., (2012). Argomentare per superare il conflitto: l'argomentazione nella mediazione. Sistemi Intelligenti. Argomentazione, processi cognitivi e nuove tecnologie, pagg.513-533.

GRECO MORASSO, S., (2011). Argumentation in Dispute Mediation, Amsterdam: John Benjamin Publishing Company.

HABERMAS, J., (2007). La condizione intersoggettiva, Roma-Bari: Laterza.

HABERMAS, J., (1986). Teoria dell'agire comunicativo, Bologna: II Mulino.

HAGEI, J. \& Barnett, R.E., (1977). Assessing the Criminal. Restitution, Retribution and the Legal Process, Cambridge (MA): Ballinger Pub. Co.

HOCHMANN, J., (2006). Die Kunst des Fragens in der Mediation. Zeitschrift für Konfliktmanagement, 2, pagg.39-52.

IRVINE, C. \& FARRINGTON, L., Mediation and Emotions: Perceptions and Regulation,

JACOBS, S. \& AAKHUS, M., (2002). What mediators do with words: Implementing three models of rational discussion in dispute mediation. Conflict resolution quarterly, 20(2), pagg.177-203.

KINSEY, W.D., Fuller, R.M. \& McKinney, B.C., (1993). Mediator Listening, Dispute Reframing, and Mediation Outcome: A Pilot Study. Internternational Listening Association Journal, 1(7), pagg.7491.

KRAYBILL, R., (1988). Training Manual for Conflict Transformation Skills, Akron (PA): Riverside Press.

KRAYBILL, R., EVANS, R. \& FRAZER EVANS, A., (2000). Peace Skills. Manual for Community Mediators, Weinheim: Wiley \& Songs.

KRAYBILL, R. \& WRIGHT, E., (2006). The little Book of Cool Tools for Hot Topics, Intercourse (PA): Good Books.

LEDERACH, J.P., (2003). The Little book of Conflict Transformation, Intercourse (PA): Good Books.

LEDERACH, J.P., (2005). The moral Imagination. The Art and Soul of building Peace, Oxford: Oxford University Press.

MAIESE, M., (2004). Ground Rules. In G. Burgess \& H. Burgess, a c. di Beyond Intractability. Boulder. MAYER, B., (2000). The Dynamics of Conflict Resolution, San Francisco: Jossey-Bass.

MCKINNEY, B.C., FULLER, R.M. \& KINSEY, W.D., (1992). Mediator communication competencies, Ednia (MN): Bourgess Publishing.

MOORE, C., (1996). The Mediation Process, San Francisco: Jossey-Bass.

MORINEAU, J., (1998). L'esprit de la médiation, Toulouse: Erès.

POIRER-ELLIOT, M.L., (1998). The role of facilitators, mediators and others. In L. Susskind, S. McKearnan, \& J. Thomas-Larmer, a c. di The Consensus Building Handbook: a Comprehensive 
Guide to Reaching Agreement. London - Thousand Oaks (CA): SAGE Publications, pag. 228 e ss.

REGGIO, F., (2017). Concordare la norma. Gli strumenti consensuali della controversia in ambito civile. Una proposta filosofico-metodologica, Padova: Cleup.

REGGIO, F., (2016). La composizione delle liti tra privati sotto il profilo metodologico. In P. Gianniti, a c. di Processo civile e soluzioni alternative delle liti. Verso un sistema di giustizia integrato. Rimini: Aracne, pagg. 119-169.

REGGIO, F., (2012). "Norma del caso» e soluzioni concordate della controversia in ambito civile. Alcune riflessioni su una «zona limite» della positività giuridica. In P. Moro \& C. Sarra, a c. di Positività e Giurisprudenza. Teoria e prassi nella formazione giudiziale del diritto. Franco Angeli, pagg. 217-245.

SANDER, F.E.A., (1979). Varieties of Dispute Processing. In A. Levin \& R. Wheeler, a c. di The Pound Conference: Perspectives on Justice in the Future. St. Paul (MN): West Publishing.

SCHIRCH, L. \& CAMPT, D., (2007). The little Book of Dialogue for difficult Subjects, Intercourse (PA): Good Books.

SLOB, W., (2002). Dialogical Rhetoric. An Essay on Truth and Normativity Afer Postmodernism., Dordrecht-Utrecht: Springer.

SMITH, R., (1996). Achieving civil Justice. Appropriate Dispute Resolution for the 1990s, Edimbourgh: Scottisch Legal Action Group.

STEWART, J. \& MILT, T., (1995). Dialogic Listening: Sculpting Mutual Meanings. In J. Stewart, a c. di Bridges Not Walls. New York, pagg. 184-201.

STULBERG, J.P., (1997). Facilitative Versus Evaluative Mediator Orientations: Piercing the "Grid» Lock. Florida State University Law Review, 4(24), pagg.985-1002.

VENDEMIATI, A., (2007). Universalismo e relativismo nell'etica contemporanea, Genova: Marietti.

WALTON, D.N. \& KRABBE, E.W.N., (1995). Commitment in dialogue: Basic concepts of interpersonal reasoning, New York: State University of New York Press.

WINSLADE, J. \& MONK, G., (2001). Narrative Mediation. A new approach to conflict resolution, San Francisco: Jossey-Bass.

WRIGHT, M., (1991). Justice for victims and offenders, Philadelphia: Open University Press.

ZEHR, H., (1990). Changing Lenses. A new Focus on Crime and Justice, Scottsdale: Herald Press. 